\title{
New Polymeric Ion Selective Electrode for Determination of Sulfamethoxazole in Pure and Pharmaceutical Samples
}

\author{
Sarra A. Abrahem and Khaleda H. Al-Saidi \\ Department of Chemistry, College of Science, Al-Nahrain University, Al-Jaderia, Baghdad-Iraq.
}

\begin{abstract}
Sulfamethoxazole ion selective electrodes were constructed based on sulfamethoxazole tengestophosphoric acid as ion pair complex in a polyvinylchloride matrix and plasticized by four plasticizers, Di-octyl phthalate (DOPH); Tri-butyl phosphate (TBP); Acetophenone (AP) and Nitrobenzene (NB). Sulfamethoxazole electrodes (E1, E2, E3 and E4) gave slopes (52.008, 58.381, 56.909 and $50.309 \mathrm{mV} /$ decade $)$ and linear ranges from $\left(1 \times 10^{-5}-1 \times 10^{-2}, 1 \times 10^{-7}-1 \times 10^{-2}, 1 \times 10^{-5}-1 \times 10^{-2}\right.$ and $\left.1 \times 10^{-5}-1 \times 10^{-2} \mathrm{M}\right)$ respectively. The best electrode (E2) was based on TBP plasticizer which gave a slope $58.381 \mathrm{mV} /$ decade, correlation coefficient 0.9997 , detection limit of $9 \times 10^{-8} \mathrm{M}$, lifetime 27 day. $\mathrm{pH}$ and life time of the electrodes were also studied and the proposed electrode displayed a good stability and reproducibility and were used to determine the Sulfamethoxazole in pharmaceutical samples. The interferences measurements in the presence of $\left(\mathrm{Na}^{+}, \mathrm{K}^{+}, \mathrm{Cu}^{+2}, \mathrm{Mn}^{+2}\right.$, $\mathrm{Fe}^{+3}, \mathrm{Al}^{+3}$, trimethoprim, starch, sucrose and gelatin) were studied using the separated method and mixed method for selectivity coefficient determination.
\end{abstract}

Keywords: Sulfamethoxazole, Tengestophosphoric acid, Ion selective electrode (ISE).

\section{Introduction}

Sulfamethoxazole (SMZ), 4-Amino- $N-(5-$ methylisoxazol-3-yl)- benzenesulfonamide, $\mathrm{C}_{10} \mathrm{H}_{11} \mathrm{~N}_{3} \mathrm{O}_{3} \mathrm{~S}$, as shown in Fig.(1), is white or almost white, crystalline powder with molecular weight $253.279 \mathrm{~g} / \mathrm{mole}$, practically insoluble in water, freely soluble in acetone, sparingly soluble in ethanol. It dissolves in dilute solutions of sodium hydroxide and in dilute acids. Sulfamethoxazole is a sulfonamide bacteriostatic antibiotic. It is most often used as part of a synergistic combination with trimethoprim in a 5:1 ratio in cotrimoxazole. ${ }^{[1]}$ Various analytical methods have been developed to determine sulfamethoxazole in formulations and biological samples, such as spectrophotometric [2,3], chromatographic ${ }^{[4,5]}$, and HPLC (High Performance Liquid Chromatography $)^{[\mathbf{6 , 7 , 8 ]}}$ methods. The applications of ion selective electrodes continue to be of interest in pharmaceutical analysis [9] and ions [10,11] because these sensors offer the advantages of simple design and operation, reasonable selectivity, fast response, low cost and applicability to turbid and colored solutions $[12,13]$. In this work the sensor is based on Sulfamethoxazole -tengestophosphoric acid as ion pair in polyvinyl chloride plasticized with different plasticizers were used for the determination of Sulfamethoxazole in pharmaceutical samples, The properties of prepared electrodes, $\mathrm{pH}$ effect and selectivity, were studied.

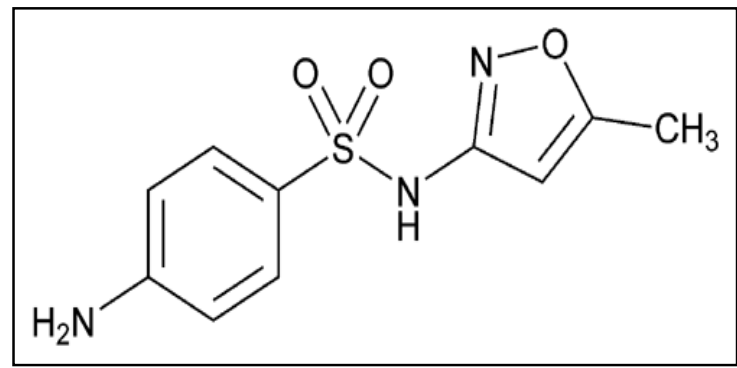

Fig. (1) Structure formula of sulfamethoxazole.

\section{Experimental Part \\ Equipment}

A digital pH/ion meter (inoLab 740 with terminal 740 - WTW, Germany) was used for all potentiometric and $\mathrm{pH}$ measurements. Hotplate Stirrer (LMS-1003, Daihan Labtech), Sartorius Handy 4digits Analytical Balance, Fourier transforms infrared spectrophotometer (FTIR-8300 SHIMADZ, Japan), pH combination electrodes (SenTix ${ }^{\circledR} 82$ WTW, Germany), Silver-silver chloride wire and Saturated Calomel reference electrode were used in this work. 


\section{Reagents and Solutions}

-Sulfamethoxazole standard was a gift from the State Company of Drug Industries and Medical Appliances (Samara IRAQ-SDI). Polyvinyl chloride (PVC) of relatively high molecular weight. Trimole tablets each tablet (containing $400 \mathrm{mg}$ Sulfamethoxazole) were purchased from Bilim pharmaceuticals (made in Emirates). Tengestophosphoric acid (TPA), Molecular Weight $2880.2 \mathrm{~g} / \mathrm{mole}$, was purchased from Fluka. DOPH, TBP, AP and NB were purchased from Fluka AG, Switzerland, Tetrahydrofuran (E.Merck). Acetone from Sigma-Aldrich. Other chemicals and solvents were of an analytical reagent grade obtained from $\mathrm{BDH}$.

-Stock solutions of $0.1 \mathrm{M}$ for each of $\mathrm{NaCl}$, $\mathrm{KCl}, \mathrm{Cu}\left(\mathrm{NO}_{3}\right)_{2} .3 \mathrm{H}_{2} \mathrm{O}, \mathrm{MnSO}_{4}, \mathrm{Fe}_{2}\left(\mathrm{SO}_{4}\right)_{3} .9 \mathrm{H}_{2} \mathrm{O}$, $\mathrm{AlCl}_{3} .6 \mathrm{H}_{2} \mathrm{O}$, trimethoprim, starch, sucrose and gelatin were prepared by dissolving 0.2922 , $0.3722, \quad 1.2077, \quad 0.7550,2.8100,1.2066$, $1.4516,0.8108,1.7115$ and $1.5000 \mathrm{~g}$ in $50 \mathrm{~mL}$ of distilled water respectively.

-A standard solution of $0.01 \mathrm{M}$ Tengestophosphoric acid (TPA) was prepared by dissolving $1.4401 \mathrm{~g}$ of pure (TPA) in distilled water and completing the solution up to $50 \mathrm{~mL}$.

-A stock solution of $10^{-2} \mathrm{M}$ Sulfamethoxazole was prepared by dissolving $0.1266 \mathrm{~g}$ of pure (SMZ) in acetone and distilled water in proportion (1:4) and completing the solution up to $50 \mathrm{~mL}$. The working solutions $10^{-8}-10^{-2} \mathrm{M}$ SMZ were prepared by serial appropriate dilution of the stock solution using the same solvent.

-Stock solution of $0.1 \mathrm{M}$ of $\mathrm{HCl}$ and $0.1 \mathrm{M}$ of $\mathrm{NaOH}$ which are used for adjusting $\mathrm{pH}$ of the solutions.

\section{Procedure}

\section{Preparation of ion pair:-}

The ion pair was prepared by mixing equal volume of $0.01 \mathrm{M}$ solution of tengestophosphoric acid (TPA) dissolved in distilled water with an equimolar solution of sulfamethoxazole(SMZ) dissolved in acetone, The precipitate formed after $24 \mathrm{hr}$.

\section{Preparation of membrane:-}

$0.0400 \mathrm{~g}$ of ion pair was mixed with $0.3600 \mathrm{~g}$ of plasticizer and $0.1700 \mathrm{~g}$ of PVC powder; all were dissolved in $5 \mathrm{ml}$ of THF with stirring until a clear viscous solution was obtained ${ }^{[14]}$.

\section{Construction of ion-selective electrodes:-}

The construction of the electrode body and the immobilization were done as described by Craggs et al. ${ }^{[14]}$. This method include that the viscous solution poured into a glass casting ring about $30 \mathrm{~mm}$ length and $35 \mathrm{~mm}$ in diameter. It consists of two pieces; one of them is the glass cylinder and the other is glass plate. The two pieces was pasted together by using (PVC-THF) viscous mixture. The glass tube was $3 / 4$ filled with $10^{-3} \mathrm{M}$ Sulfamethoxazole solution as an internal filling solution, the membrane was conditioned by immersing in a standard solution of the same concentration for at least 4 hour before measurements.

\section{Potential Measurements}

The potential was carried out at room temperature. The electrochemical cell may be represented as follows:

$\mathrm{Ag} / \mathrm{AgCl}$ |internal filling solution|| membrane ||test solution| SCE

A calibration curve was constructed for each electrode using standard analyte solutions ranged from $\left(10^{-8}-10^{-2} \mathrm{M}\right)$. The calibration curves were prepared by plotting the potential E versus concentration (M) log scale by using computer program (Microsoft office Excel 2010).

\section{Preparation of Pharmaceutical Samples}

Ten tablets of trimole each tablet containing $400 \mathrm{mg}$ of sulfamethoxazole weighted accurately and grinded it found that the weight of average of one tablet was $0.6656 \mathrm{~g}$ to prepare $10^{-2} \mathrm{M}$ from sulfamethoxazole $0.2107 \mathrm{~g}$ was dissolved in $10 \mathrm{~mL}$ acetone and then filtered and completing the solution up to $50 \mathrm{~mL}$ with distilled water. Other samples prepared by dilution.

\section{Calculation of Selectivity coefficient}

A separate solution method ${ }^{[15]}$ was used for the selectivity coefficient measurement, which calculated according to the equation:

$\log \mathrm{K}^{\mathrm{pot}}{ }_{\mathrm{A}, \mathrm{B}}=\left(\mathrm{E}_{\mathrm{B}}-\mathrm{E}_{\mathrm{A}}\right) / \mathrm{S}+\left(1-\mathrm{Z}_{\mathrm{A}} / \mathrm{z}_{\mathrm{B}}\right) \log \mathrm{a}_{\mathrm{A}}$ 
$\mathrm{E}_{\mathrm{A}}, \mathrm{E}_{\mathrm{B}} ; \mathrm{z}_{\mathrm{A}}, \mathrm{z}_{\mathrm{B}}$; and $\mathrm{a}_{\mathrm{A}}$, are the potentials, charge numbers, and activities for the primary A ion, respectively, at $\mathrm{a}_{\mathrm{A}}=\mathrm{a}_{\mathrm{B}}$.

The selectivity coefficients were also measured by the mixed method (Fixed interference method) (FIM) ${ }^{[16,17]}$ according to the equation:

$\mathrm{K}^{\mathrm{pot}}{ }_{\mathrm{A}, \mathrm{B}}=\mathrm{a}_{\mathrm{A}} /\left(\mathrm{a}_{\mathrm{B}}\right)^{\mathrm{zA} / \mathrm{zB}}$

\section{Results and Discussion}

Four electrodes of sulfamethoxazole (SMZ) (E1, E2, E3, E4) based on using SMZ, TPA and used four plasticizers: DOPH, TBP, AP and NB with PVC matrix were examined respectively.

The sensor (E2) displays a linear response from $10^{-7}$ to $10^{-2} \mathrm{M}$ (SMZ) with Nernstian cationic slope of $58.381 \mathrm{mV} /$ decade with lower limit of detection of $9 \times 10^{-8} \mathrm{M}$, which was calculated at the point of intersection of the extrapolated segments of the two linear parts of the calibration curve of SMZ. Electrode (E2) gave high slope value because the high mixing between the TBP and PVC due to the compatibility of the plasticizer used to the electro-active compound in both structure and composition. A typical plot for calibration curves of electrodes based on four plasticizers DOPH, TBP, AP and NB are shown in Fig.(2).

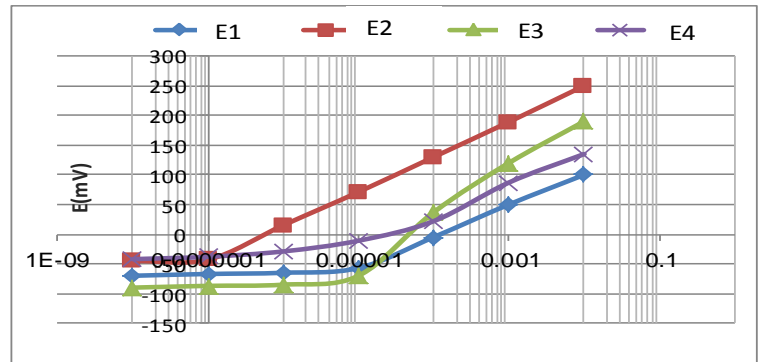

Fig.(2) Calibration curves of

Sulfamethoxazole selective electrodes using $D O P H, T B P, A P$ and NB plasticizer.

The FTIR spectrum of the complex was compared with the reference spectrum of sulfamethoxazole [18], Fig.(3- a and b). The spectrums show a good purity and the functional groups obtained from the spectrum were shown in Table (1).

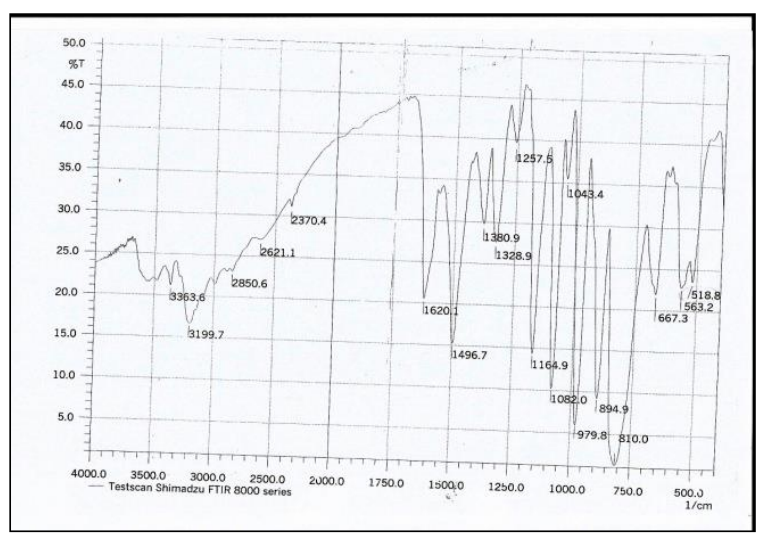

Fig.(3) a- FTIR spectrum of complex (SMZ-TPA).

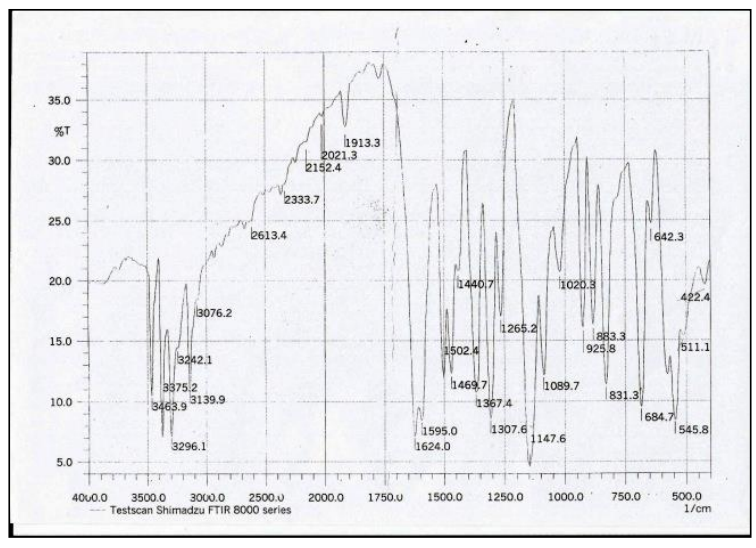

b- FTIR reference spectrum of pure SMZ.

Table (1)

The functional groups obtained from the spectrum for each SMZ and complex [SMZ-TPA].

\begin{tabular}{|c||c||c||}
\hline $\begin{array}{c}\text { Functional } \\
\text { groups }\end{array}$ & $\begin{array}{c}\text { Sulfamethoxazole } \\
\text { (SMZ) } \\
\text { cm }^{-1}\end{array}$ & $\begin{array}{c}\text { Complex } \\
\text { [SMZ- } \\
\text { TPA] } \\
\text { cm }^{-1}\end{array}$ \\
\hline \hline$v(\mathrm{~N}-\mathrm{H})$ & 3463 & 3199 \\
\hline$v(\mathrm{~S}=\mathrm{O})$ & 1307 & 1328 \\
\hline \hline Bending $(\mathrm{N}-\mathrm{H})$ & 1595 & 1620 \\
\hline \hline$v(\mathrm{~N}=\mathrm{C})$ & 1624 & 1620 \\
\hline
\end{tabular}

The slopes were obtained for electrodes based on DOPH, AP and NB (membranes E1, $\mathrm{E} 3$ and E4), and the values were 52.008, 56.909 and $50.309 \mathrm{mV} /$ decade with correlation coefficients of $0.9991,0.9994$ and 0.9981 respectively. The linear range for these electrodes $1 \times 10^{-5}-1 \times 10^{-2}, 1 \times 10^{-5}-1 \times 10^{-2}$ and $1 \times 10^{-5}-1 \times 10^{-2} \mathrm{M}$ with detection limits of $9 \times 10^{-6}, 6 \times 10^{-6}$ and $7 \times 10^{-6} \mathrm{M}$, respectively. The results and other parameters are given in Table (2). The electrodes gave different Nernst slopes, this could be due to the different 
viscosities of plasticizers; for example, the high viscosity decrease the ion-exchange process and the low viscosity causes rapid leaching of the membrane components to the external solution ${ }^{[19]}$.

Table (2)

The parameters for four (SMZ) electrodes.

\begin{tabular}{|c|c|c|c|c|c|c|c|c|c|}
\hline \multirow[b]{2}{*}{ Electrode } & \multirow[b]{2}{*}{$\begin{array}{c}\text { Slope } \\
\text { (mV/Decade) }\end{array}$} & \multirow[b]{2}{*}{ Linear equation } & \multirow[b]{2}{*}{\begin{tabular}{||c} 
Correlation \\
coefficient $(r)$
\end{tabular}} & \multirow[b]{2}{*}{$\begin{array}{c}\text { Linear concentration } \\
\text { range }(M)\end{array}$} & \multirow[b]{2}{*}{$\mid \begin{array}{l}\text { Detection } \\
\text { limit }(M)\end{array}$} & \multicolumn{3}{|c|}{ Response time (sec) } & \multirow[b]{2}{*}{$\begin{array}{l}\text { Lifetime } \\
\text { (day) }\end{array}$} \\
\hline & & & & & & $\begin{array}{c}1 \times 10^{-2} \\
(M)\end{array}$ & $\begin{array}{c}1 \times 10^{-3} \\
(M)\end{array}$ & $\begin{array}{c}1 \times 10^{-4} \\
(M)\end{array}$ & \\
\hline $\begin{array}{c}\text { E1 } \\
\text { SMZ+TPA+ } \\
\text { DOPH } \\
\end{array}$ & 52.008 & $\begin{array}{c}\mathrm{y}=22.583 \ln (\mathrm{x})+ \\
210\end{array}$ & 0.9991 & $1 \times 10^{-5}-1 \times 10^{-2}$ & $9 \times 10-6$ & 26 & 30 & 37 & 29 \\
\hline $\begin{array}{c}\text { E2 } \\
\text { SMZ +TPA+ } \\
\text { TBP } \\
\end{array}$ & 58.381 & $\begin{array}{c}y=25.35 \ln (x)+ \\
364.17\end{array}$ & 0.9997 & $1 \times 10^{-7}-1 \times 10^{-2}$ & $9 \times 10-8$ & 24 & 28 & 36 & 27 \\
\hline $\begin{array}{c}\text { E3 } \\
\text { SMZ +TPA+ } \\
\text { AP } \\
\end{array}$ & 56.909 & $\mathrm{y}=24.711 \ln (\mathrm{x})+$ & 0.9994 & $1 \times 10^{-5}-1 \times 10^{-2}$ & $6 \times 10-6$ & 29 & 36 & 42 & 20 \\
\hline $\begin{array}{c}\mathrm{E} 4 \\
\mathrm{SMZ}+\mathrm{TPA}+ \\
\mathrm{NB} \\
\end{array}$ & 50.309 & $\mathrm{y}=21.8451 \ln (\mathrm{x})+$ & 0.9981 & $1 \times 10^{-5}-1 \times 10^{-2}$ & $7 \times 10-6$ & 22 & 25 & 33 & 9 \\
\hline
\end{tabular}

\section{Effect of pH:-}

The effect of $\mathrm{pH}$ on the electrode potentials for SMZ selective membrane electrode E2 was examined by measuring the potential of the cell in SMZ solutions at three different concentrations $\left(1 \times 10^{-2}, 1 \times 10^{-3}, 1 \times 10^{-4}\right)$ $\mathrm{M}$ in which the $\mathrm{pH}$ ranged from (0.5-11.0). The $\mathrm{pH}$ adjusted by adding appropriate amounts of hydrochloric acid and/or sodium hydroxide solution. The results shown in Fig.(4).

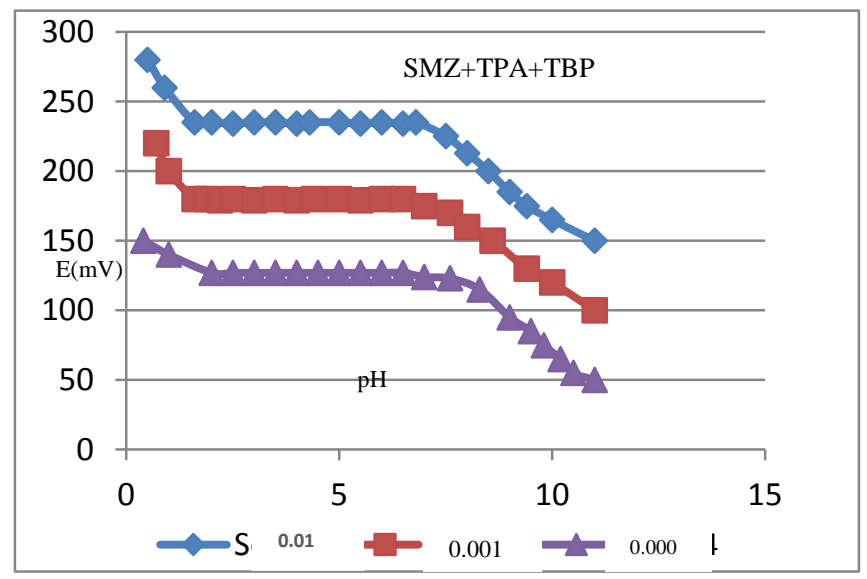

Fig.(4) Effect of $p H$ on the potential of the electrode E2 at concentrations $1 \times 10^{-2}, 1 \times 10^{-3}$ and $1 \times 10^{-4} \mathrm{M}$.

At $\mathrm{pH}$ values less than 1.6 or in very high acidity, the electrode response has been increased rather irregularly. This may be due to that the electrode response to $\mathrm{H}^{+}$activities as well as SMZ ions and in an alkaline solution ( $\mathrm{pH}$ greater than 7$)$ the electrode response has been decreased, may attribute to the decreasing in the solubility of SMZ. ${ }^{[20]}$ The working $\mathrm{pH}$ were tabulated in Table (3).

Table (3)

Working $\mathrm{pH}$ ranges for (SMZ) electrode (E2). for $\left(1 \times 10^{-2}, 1 \times 10^{-3}\right.$ and $\left.1 \times 10^{-4}\right)$ M of SMZ.

\begin{tabular}{|c|c|c|c|c|}
\hline \multirow[b]{2}{*}{$\begin{array}{c}\text { Electrode } \\
\text { no. }\end{array}$} & \multirow[b]{2}{*}{$\begin{array}{c}\text { Composition of } \\
\text { electrode E2 }\end{array}$} & \multicolumn{3}{|c|}{ pH range } \\
\hline & & $\begin{array}{c}1 \times 10^{-2} \\
(\mathrm{M})\end{array}$ & $\begin{array}{c}1 \times 10^{-3} \\
(\mathrm{M})\end{array}$ & $\begin{array}{c}1 \times 10^{-4} \\
(\mathrm{M})\end{array}$ \\
\hline E2 & SMZ+TPA+TBP & $1.6-6.8$ & $1.6-6.5$ & $2.0-6.5$ \\
\hline
\end{tabular}

\section{Interference studies:-}

In order to investigate the selectivity of the proposed membrane (E2) ion selective electrode toward sulfamethoxazole with respect to various interfering ions by using: separate solution method according to equation (1) and mixed solution method according to equation (2). The values of the selectivity coefficients for separate method and mixed method are listed in Table (4) and Fig.(5) show the calibration curve of fixed interfering method sulfamethoxazole selective electrode (E2) for sodium ion $\left(\mathrm{Na}^{+}\right)$. 
Table (4)

Values of $K^{p o t}{ }_{A, B}$ according to separate method and FIM by using electrode E2.

\begin{tabular}{|c|c|c|c|}
\hline \multirow{2}{*}{ Interfering ions } & Separate & method & Mixed method \\
\hline & $\log ^{p o t}{ }_{A, B}$ & $K^{p o t}{ }_{A, B}$ & $K^{p o t}{ }_{A, B}$ \\
\hline $\mathrm{Na}^{+}$ & -2.119 & $7.59 \times 10^{-3}$ & $3.40 \times 10^{--6}$ \\
\hline$K^{+}$ & -2.205 & $6.23 \times 10^{-3}$ & $3.00 \times 10^{-6}$ \\
\hline$\overline{C u^{+2}}$ & -4.102 & $7.91 \times 10^{-5}$ & $3.35 \times 10^{--7}$ \\
\hline$M n^{+2}$ & -4.239 & $5.76 \times 10^{-5}$ & $3.57 \times 10^{-7}$ \\
\hline $\mathrm{Fe}^{+3}$ & -4.825 & $1.49 \times 10^{-5}$ & $5.42 \times 10^{-7}$ \\
\hline$\overline{A l^{+2}}$ & -4.894 & $1.27 \times 10^{-5}$ & $1.62 \times 10^{-7}$ \\
\hline Trimethoprim & -2.239 & $5.75 \times 10^{-3}$ & $6.00 \times 10^{--6}$ \\
\hline Starch & -2.464 & $3.43 \times 10^{-3}$ & $1.80 \times 10^{-6}$ \\
\hline Sucrose & -2.670 & $2.13 \times 10^{-3}$ & $1.40 \times 10^{--6}$ \\
\hline Gelatin & -2.705 & $1.97 \times 10^{-3}$ & $1.30 \times 10^{-6}$ \\
\hline
\end{tabular}

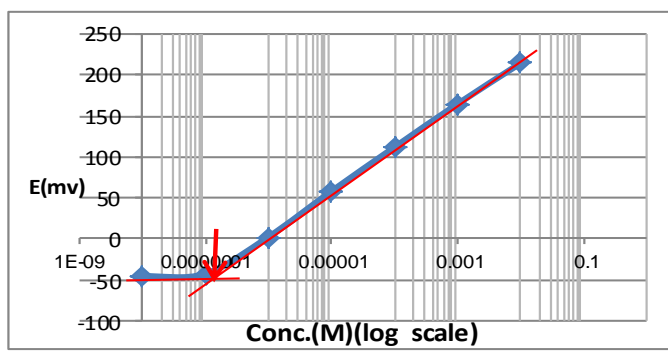

Fig. (5) Calibration curve of fixed interfering method sulfamethoxazole selective electrode (E2).

\section{Sample analyses:-}

Four potentiometric techniques were used for the determination of sulfamethoxazole including. Direct method and standard addition method (SAM) follows the equation:

$\mathrm{C}_{\mathrm{U}}=\mathrm{C}_{\mathrm{S}} / 10^{\Delta \mathrm{E} / \mathrm{S}}\left[1+\left(\mathrm{V}_{\mathrm{U}} / \mathrm{V}_{\mathrm{S}}\right)\right]-\left(\mathrm{V}_{\mathrm{U}} / \mathrm{V}_{\mathrm{S}}\right)$

Where $\mathrm{C}_{\mathrm{U}}, \mathrm{C}_{\mathrm{S}}, \mathrm{V}_{\mathrm{U}}$ and $\mathrm{V}_{\mathrm{S}}$ are the concentration and volume of unknown and standard solution respectively and Multiple standard additions (MSA) follows the equation:

$$
\mathrm{C}_{\mathrm{U}}=\mathrm{V}_{\mathrm{S}} \times \mathrm{C}_{\mathrm{S}} / \mathrm{V}_{\mathrm{U}}
$$

Where $\mathrm{C}_{U}$ and $\mathrm{C}_{S}$ are the concentration of unknown and standard, respectively, $\mathrm{V}_{\mathrm{S}}$ is the volume of standard solution. The method was carried out as in Fig.(6).

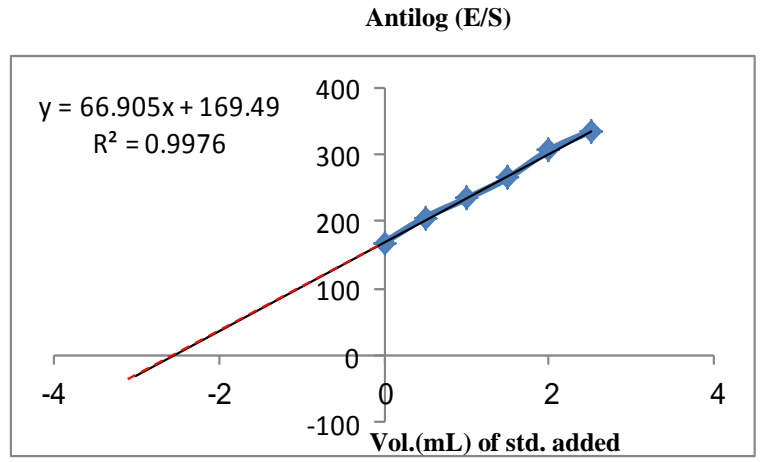

Fig.(6) Calibration curve of antilog (E/S) versus the volume added of standard $10^{-3} \mathrm{M}$ for determination of $25 \mathrm{~mL}$ sulfamethoxazole solution $10^{-4} \mathrm{M}$ by (MSA).

by plotting antilog $(\mathrm{E} / \mathrm{S})$ versus the volume of the five addition of standard sulfamethoxazole, used to of concentration can be covered as compared with working range calibration curve for MSA used to determine the concentration of sulfamethoxazole. For potentiometric titration a $10^{-4} \mathrm{M}$ of tengestophosphoric acid were used as a titrant. A typical titration plot were shown in Fig.(7) (a ,b and c) 


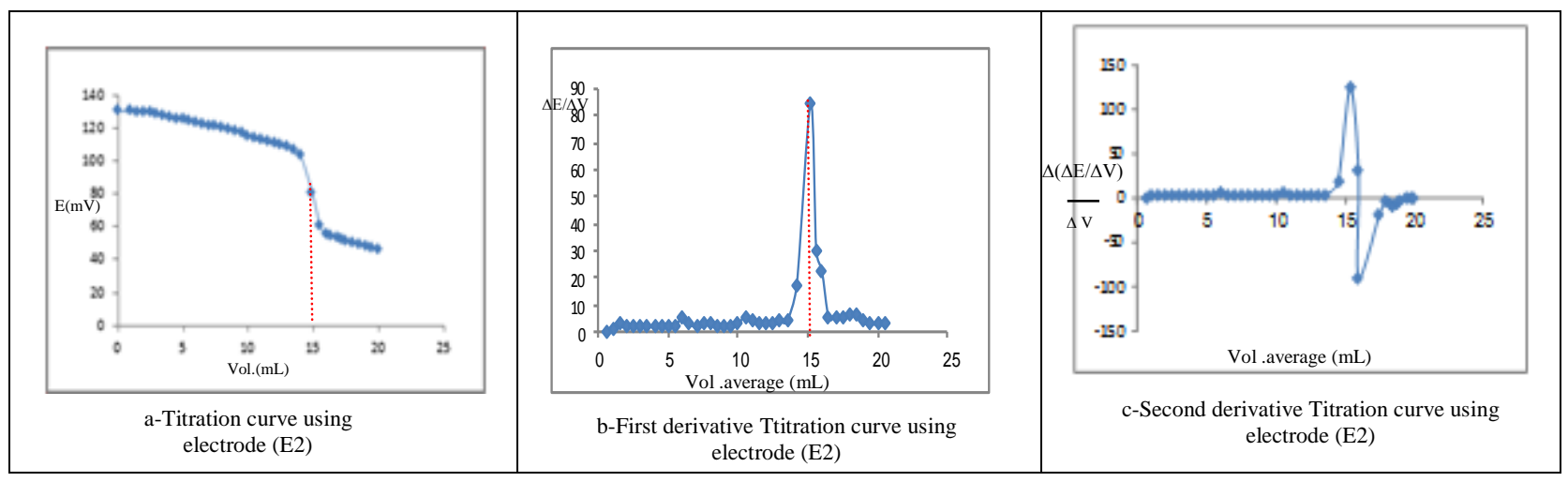

Fig.(7)(a, b and c) Titration curves of sulfamethoxazoleselective electrode using TBP plasticizer.

The recovery $(\operatorname{Re} \%)$, relative error $\left(\mathrm{E}_{\mathrm{r}} \%\right)$ and relative standard deviation (RSD \%) for each method are calculated and the results are listed in Table (5). The electrode (E2) was proved to be useful in the potentiometric determination of sulfamethoxazole in pharmaceutical preparations and the data obtained for pharmaceutical samples were listed in Table (6).

Table (5)

Analysis of SMZ by potentiometric techniques by using ISE E2.

\begin{tabular}{|c|c|c|c|c|}
\hline Parameter & Direct method** & $\overline{S A M *}$ & Multi SAM* & Titration method $* * *$ \\
\hline Conc. $(M)$ & $1.000 \times 10^{-4}$ & $1.000 \times 10^{-4}$ & $1.000 \times 10^{-4}$ & $1.000 \times 10^{-4}$ \\
\hline Found(M) & $0.996 \times 10^{-4}$ & $0.988 \times 10^{-4}$ & $1.013 \times 10^{-4}$ & $1.011 \times 10^{-4}$ \\
\hline$R S D^{*} \%$ & $0.411 \%$ & $0.532 \%$ & "--------- & $1.659 \%$ \\
\hline $\operatorname{Re} \%$ & $99.660 \%$ & $98.860 \%$ & $101.320 \%$ & $101.110 \%$ \\
\hline Er\% & $-0.340 \%$ & $-1.14 \%$ & $1.320 \%$ & $1.110 \%$ \\
\hline$S$ & $4.098 \times 10^{-7}$ & $5.263 \times 10^{-7}$ & "--------- & $1.677 \times 10^{-6}$ \\
\hline$x \pm(t s / \sqrt{ } N)$ & $0.996 \times 10^{-4} \pm 0.494 \times 10^{-6}$ & $0.988 \times 10^{-4} \pm 0.635 \times 10^{-6}$ & "--------- & $1.011 \times 10^{-4} \pm 0.416 \times 10^{-5}$ \\
\hline
\end{tabular}

Table (6)

Analyses of SMZ inpharmaceutical samples.

\begin{tabular}{|c|c|c|c|c|}
\hline Parameter & Direct method* & $\overline{S A M *}$ & Multi SAM* & Titration method $* * * *$ \\
\hline Conc. $(M)$ & $1.000 \times 10^{-4}$ & $1.000 \times 10^{-4}$ & $1.000 \times 10^{-4}$ & $1.000 \times 10^{-4}$ \\
\hline Found(M) & $0.998 \times 10^{-4}$ & $0.998 \times 10^{-4}$ & $1.002 \times 10^{-4}$ & $0.999 \times 10^{-4}$ \\
\hline$R S D^{*} \%$ & $0.647 \%$ & $0.753 \%$ & --------- & $0.919 \%$ \\
\hline $\operatorname{Re} \%$ & $99.820 \%$ & $99.8 \%$ & $100.200 \%$ & $99.95 \%$ \\
\hline Er\% & $-0.180 \%$ & $-0.200 \%$ & $0.200 \%$ & $-0.05 \%$ \\
\hline$S$ & $6.457 \times 10^{-7}$ & $7.516 \times 10^{-7}$ & --------- & $9.192 \times 10^{-7}$ \\
\hline$x \pm(t s / N)$ & $0.998 \times 10^{-4} \pm 0.779 \times 10^{-6}$ & $0.998 \times 10^{-4} \pm 0.907 \times 10^{-6}$ & --------- & $0.999 \times 10^{-4} \pm 0.825 \times 10^{-5}$ \\
\hline
\end{tabular}

$R S D * * \%$ for $n=2, t=12.7$

$R S D * \%$ for $n=3, t=4.3$

$R S D * \%$ for $n=5, t=2.7$ 


\section{Conclusions}

ISE method included formation of membranes for sulfamethoxazole was constructed based on using sulfamethoxazole (SMZ) and tengestophosphoric acid (TPA) as ion pair dissolving in many plasticizers. The best electrode for SMZ was (E2) electrode which used to determine SMZ in the pharmaceutical samples. Also there is no interference for some interfering ions. The proposed analytical method is proved to be simple and rapid, with good accuracy.

\section{References}

[1] British pharmacopoeia; "Medicinal and Pharmaceutical Substances"; Published by The Stationery Office on behalf of the Medicines and Healthcare products Regulatory Agency (MHRA); Vol. 1 \& 2; pp. 1406-1407; 2014.

[2] Jasmin S.; Rasul M.J.; Suraya M.; "Extractive Spectrophotometric Methods for Determination of Sulfamethoxazole in Pharmaceutical Formulations Using Bromothymol Blue and Cresol Red"; J. Chin. Chem. Soc. 55, 1107-1112, 2008.

[3] Mohamed E.; Safaa El-Din H.E.; "Spectrophotometric methods for estimation of sulfamethoxazole based on charge transfer complexes"; Canadian J. Anal. Sci. Spec. 52, 316-324, 2007.

[4] Jiang Y.; Wang J.; Li H.; Wang Y.; Gu J.; "Determination of sulfamethoxazole in human plasma by liquid chromatographyelectrospray ionization tandem mass spectrometry"; J Pharm Biomed Anal. 43, 1460-1464, 2007.

[5] Punnamchand L.; Poornima D.H.; " $A$ simple, rapid, and sensitive HPTLC method for the estimation of sulfamethoxazole: Application to single dose clinical study"; J Planar Chrom. 24, 534-538, 2012.

[6] Wei L.; Huijuan J.; Kang Z.; "Determination of sulfamethoxazole in rat plasma by HPLC-UV method with pre-column derivatization"; Talanta 71, 385-390, 2007.

[7] Wibawa J.I.D.; Shaw P.N; Barrett D.A; "Quantification of sulfamethoxazole and decladinose metabolites in rat plasma, gastric juice and gastric tissue using highperformance liquid chromatography with electrochemical detection"; J. Chromatogr. B 783, 359-366, 2006.

[8] Pappa-Louisi A.; Papageorgiou A.; Zitrou A.; Sotiropoulos S.; Georgarakis E.; Zougrou F.; "Study on the electrochemical detection of the macrolide antibiotics sulfamethoxazole and trimethoprim in reversed-phase high-performance liquid chromatography"; J. Chromatogr. Biomed. Appl. 755, 57-64, 2001.

[9] Khaleda H. Al-Saidi and Haider Q. Munshid.; "New Polymeric Membrane Electrode for Clarithromycin Determination"; journal of Al-Nahrain University-Sciencem

JNUS.Vol.16,No.2,pp.30-36, 2013.

[10] Sulekh Chandra, Kusum Sharma, and Adarsh Kumar; "Mg(II) Selective PVC Membrane Electrode Based on Methyl Phenyl Semicarbazone as an Ionophore"; Journal of Chemistry, Vol. 2013, Article ID 189464, 7 pages, 2013.

[11] Khaleda H. Al-Saidi and Zainab Watheq Ahmed.; "Construction of Indium (III) Selective electrodes based on promethazine Hydrochloride in a PVC Matrix Membrane".; AL-Mustansiriya J.Sci. Vol.22, No.4, pp.147-158, 2011.

[12] C. Rundle, "A Beginners Guide to IonSelective Electrode Measurements", Nico 2000 Ltd, London, UK, 2008.

[13] J. Koryta, "Theory and applications of ion-selective electrodes part II", Anal. Chem. Acta, Vol. 91, No. 1, pp. 1-85, 1977.

[14] Craggs A.; Moody G.J.; Thomas, J.D.R.; "PVC matrix membrane ion-selective electrodes. Construction and laboratory experiments"; Chem. Educ. 8, pp. 541-544, 1974.

[15] Umezawa, Y.; Umezawa, K. and Sato, H., "Selectivity Coefficients for Ion Selective Electrodes", Pure Appl. Chem., Vol.67, pp. 508-518, 1995.

[16] Umezawa, Y.; Umezawa, K.; Bhlmann, P.; Tohda, K. and Amemiya, S., "Potentiometry Selectivity Coefficients of Ion-Selective Electrodes", Pure and Appl. Chem., Vol. 72, No. 10, pp. 1851-2082, 2000.

[17] Susan, S.; Mohammad, T. and Hossein, N., Wiley Interscience Journal, Vol. 96, Issue 1-2, pp. 65-74, 2006. 
[18] Najwa I.A.; Abdul-Muhsin A.; Moen I.A.;

Nabil S.N.; "Construction and

Characterization of Indium Liquid Ion

Selective Electrodes Based on Crown

Ethers in a PVC Matrix Membrane"; Turk.

J. Chem. 29, 687-696, 2005.

[19] British pharmacopoeia; "Infrared

Reference Spectra"; Published by The

Stationery Office on behalf of the

Medicines and Healthcare products

Regulatory Agency (MHRA); Vol. 4; p 10638; 2014.

[20] Skoog D.A.; West D.M.; Holler F.J.;

"Fundamentals of Analytical Chemistry";

Eighth edition, p.621, 2009.

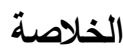

نم تحضير أقطاب بوليمرية حساسة لتقدير

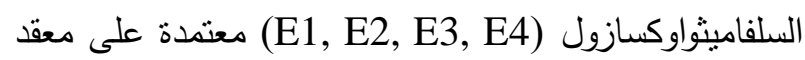

المزدوج الايوني (سلفاميثواوكسازول -حامض التتكستوفوسفوريك)

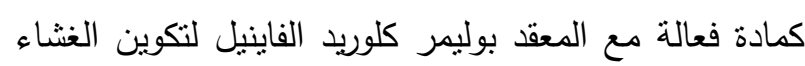

وتوكون مذابة في اربعة مواد ملدنه هي : داي اوكتيل فناليت،

تراي بيوتيل فوسفيت، أسيتوفينون ونايتروبنزين على التوالي.

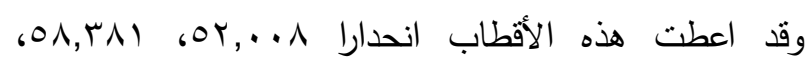

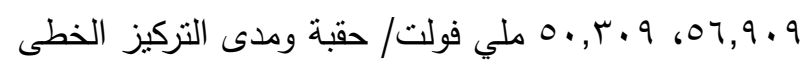

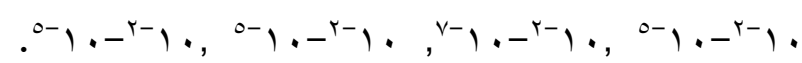

وكان أفضل قطب E2 الذي يعتمد على تراي بيوتيل فوسفيت

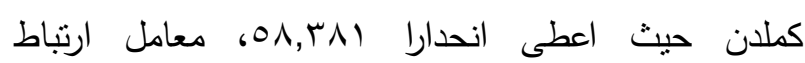

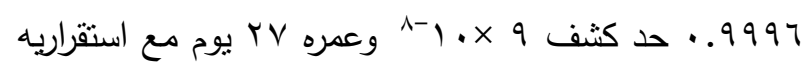

وتكرارية جيدة، لتقدير السلفاميثواوكسازول في المستحضرات

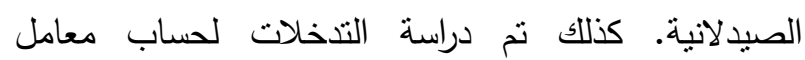

الانتقائية بطريقة المحاليل المنفصلة وطريقة المحاليل

sucrose, starch, الممزوجة بوجود الايونات و المواد التالية

trimethoprim, $\mathrm{Fe}^{+3}, \mathrm{Al}^{+3}, \mathrm{Cu}^{+2}, \mathrm{Mn}^{+2}, \mathrm{~K}^{+}, \mathrm{Na}^{+}$

gelatin 